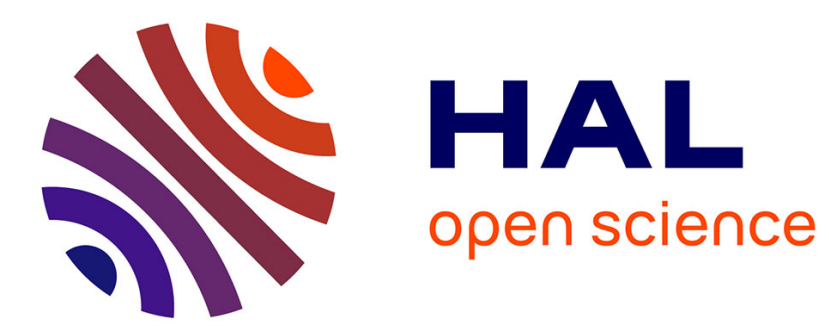

\title{
What drives the market value of firms in the defense industry?
}

Gunther Capelle-Blancard, Nicolas Couderc

\section{To cite this version:}

Gunther Capelle-Blancard, Nicolas Couderc. What drives the market value of firms in the defense industry?. 2006. halshs-00115655

\section{HAL Id: halshs-00115655 \\ https://shs.hal.science/halshs-00115655}

Submitted on 22 Nov 2006

HAL is a multi-disciplinary open access archive for the deposit and dissemination of scientific research documents, whether they are published or not. The documents may come from teaching and research institutions in France or abroad, or from public or private research centers.
L'archive ouverte pluridisciplinaire HAL, est destinée au dépôt et à la diffusion de documents scientifiques de niveau recherche, publiés ou non, émanant des établissements d'enseignement et de recherche français ou étrangers, des laboratoires publics ou privés. 


\section{Centre d'Economie de la Sorbonne}

UMR 8174

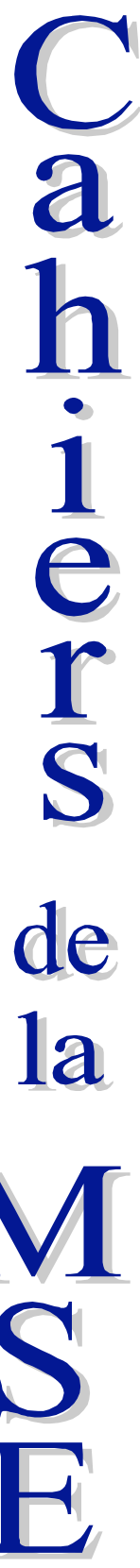

What drives the market value of

firms in the Defense industry?

Gunther CAPELLE-BLANCARD

Nicolas COUDERC

2006.37

CENTRE NATIONAL

DE LARECHERCHE

SCENTIFIQUE 


\title{
What drives the market value of firms in the Defense industry?
}

\author{
Gunther Capelle-Blancard* \\ Nicolas Couderc**
}

First version: Dec. 2005

This version: 12 April 2006

\footnotetext{
$\square$ The authors thank Stéphanie Monjon, Julien Vauday and Sylvain Daffix for helpful comments. We also would like to thank Betsy Annen and Christine Stachowiak for excellent research assistance. Any remaining errors are ours. Financial support from the Observatoire économique de la défense (French Ministry of Defense) is acknowledged.

EconomiX Université Paris X Nanterre, CES Université Paris 1 \& CNRS. Email: gunther.capelle-blancard@univ-paris1.fr.

Corresponding author. Centre d'Economie de la Sorbonne (CES), Université Paris 1 \& CNRS. 106-112 Bd de l'Hôpital 75647 Paris Cedex 13. Phone: 331440782 71. Email: couderc@univ-paris1.fr.
} 


\section{Quels évènements influencent la capitalisation boursière}

\section{des entreprises de la Défense?}

Résumé: Cet article vise à mesurer l'influence relative de différents types d'informations sur le cours boursiers d'entreprises du secteur de la Défense, au moyen d'une étude d'évènements systématique sur 58 grandes entreprises de la Défense, sur la période 1995-2005. Dans un premier temps, nous identifions les rendements boursiers anormaux statistiquement significatifs pour chaque entreprise. Dans un second temps, nous procédons à une recherche d'informations susceptibles d'expliquer ces rendements anormaux. Nos résultats montrent que les cours boursiers des entreprises de la Défense sont affectés, comme ceux des autres secteurs, par les annonces de bénéfices et de résultats, par la publication de recommendations d'analystes, etc. Le secteur de la Défense possède toutefois plusieurs spécificités, puisque les évènements géopolitiques, les informations liées aux contrats, et celles liées aux opérations de fusion-acquisitions pèsent d'un poids particulier sur les cours de ces entreprises.

Mots-clés : Etude d'évènements, marchés financiers, secteur de la Défense, publication d'informations, modèles GARCH.

Classification JEL : G14, G34, L64.

\section{What Drives the Market Value of Firms in the Defense Industry?}

Abstract: This paper investigates the relative importance of different types of news in driving significant stock price changes of firms in the defense industry. We implement a systematic event study with a sample of the 58 largest publicly listed companies in the defense industry, over the time period 1995-2005. We first identify, for each firm, the statistically significant abnormal returns over the time period, and then we look for information releases likely to cause such stock price movements. We find that stock price movements in the defense industry are, in many ways, influenced by the same events as in other industries (key role of formal earnings announcements or analysts' recommendations) but this industry also has some specific features, in particular the influence of geopolitical events and the relevance and frequency of bids and contracts on stock prices.

Keywords: Event study, financial markets, defense industry, information releases, GARCH models. 


\section{Introduction}

This paper investigates the relative importance of different types of news in driving significant changes in firms' market value in the defense industry. Many studies place great emphasis on the changing nature of the defense industry. Since the end of the Cold War, almost all defense firms have been affected by liberalization and far-reaching structural changes and concentration processes, and one can argue that defense firms have now lost their singular status. However, some specific features of the defense industry remain: the oligopoly structure of the market, the close relationships between defense firms and governments, the key role of public budgets devoted to military expenditure, the high level of R\&D, the influence on firms of geopolitical events, etc.

While many studies focus on the specificities of the defense industry (see, for instance, Markusen and Costigan, 1999; Susman and O'Keefe, 1999), none of them, to our knowledge, examine this issue from the financial market point of view. But as financial markets play an increasingly significant role in resource allocation, there is a need for a better understanding of investor behavior vis-à-vis the defense industry. Therefore, this paper attempts to contribute to the debate by addressing the following question: are the specific features of the defense firms important from the investor point of view? In other words, does the stock market react differently for defense firms than for other firms?

In particular, we analyze the relative impact of rumors, formal announcements, and unforeseeable events on the stock returns of defense firms. We study also whether investors in defense firms react more to firm-specific news or to general news (geopolitical instability, announcements of military expenditures, etc.), and whether they react more to financial or to industrial concerns. We finally assess the relative significance of seventeen categories of news (news related to bids, earnings, company restructuring, new contracts, etc.) in driving the market value of defense firms.

Given our goals, one would conduct a standard event study. Event study is a tool widely used in finance to investigate the reaction of the stock market to a specific type of news or event (such as mergers, seasoned equity offerings, earnings forecasts, etc.). However, we cannot adopt the traditional event study methodology, focusing on a single or even several a priori defined types of news because there is no way of being sure to capture the news items that are the strongest stock price movers, all the more so since the defense industry is expected to be 
specific. In addition, the results would always be conditional on the initial definition of the categories. We therefore adopt a different research design, based upon a new methodology, following Ryan and Taffler (2004). With this approach, we are not constrained by an a priori determined set of information events. We first identify, for a given firm, the statistically significant abnormal stock returns over the time period. We then look for for information releases likely to cause such abnormal returns, focusing on the largest variations (the five largest increases and the five largest decreases). On the methodological side, the contribution of this paper is twofold: we consider time-varying beta estimates by implementing rolling regressions and we use a GARCH process to model the volatility.

Our main results can be summarized as follows. First, changes in the market value of firms in the defense industry are, in many ways, driven by the same forces as in other industries. The most important news categories for explaining abnormal returns are roughly the same (earnings announcements, analysts' recommendations, etc.), and one third of the largest significant stock price changes are not related to an information release (i.e. are unexplained), which is consistent with the results of Ryan and Tafler (2004) on a broad sample of firms. Nevertheless, three specific features of the defense industry must be underlined: i) The high frequency of bid-related news: nearly $15 \%$ of our sample of the largest abnormal returns are related to such announcements. ii) The relevance of geopolitical events: $8.1 \%$ of our sample of the largest abnormal returns is due to such events. iii) The importance of public military spending: $5.4 \%$ of our sample of the largest abnormal returns is driven by this type of news.

The paper proceeds as follows. The next section (section 2) presents the sample selection, while Section 3 is about methodology. Section 4 provides both a quantitative and a qualitative analysis of our results. The final section serves as the conclusion.

\section{Data}

The first step in conducting the study is to define the sample of defense-related firms. In order to have a representative sample and to avoid any selection bias, we start with the 2003 edition of the "World Top 100 Defense Firms", a ranking published annually since 1991 by Defense News Media Group, a subdivision of Army Times Publishing Company. The ranking is based on annual defense sales. The average defense revenue is about USD 2.4 billion and the 
standard error is above USD 5 billion (see Table 1 for descriptive statistics). The biggest defense firm is Lockheed Martin ${ }^{1}$; its defense revenue is more than USD 30 billion. At the other end of the spectrum, Baltiisky Zavod has defense revenue of USD 260 million. If US firms represent nearly half of the population (42 firms out of 100 and 5 of the top 6), firms from 18 other countries also figure in the ranking: 19 firms from continental Europe, 11 from the UK, 8 from Japan, 7 from Russia, etc. US firms also account for nearly $2 / 3$ of the total defense revenue (USD 160 billion), followed by UK firms (27 billion).

In order to obtain a coherent sample for our study, we apply some exclusion criteria. As we are only interested in publicly listed companies, we drop out of the sample:

- fully and partly state-owned firms (6 firms: DCN, Israel Aircraft Industries, GIAT Industries, Ruag Suisse, Rafael Armament Development Authority, Israel Military Industries);

- family-owned firms (2 firms: Krauss-Maffei Wegmann and Diehl Stiftung);

- firms with one dominant shareholder or with a low (below 25\%) free float rate (3 firms: IZAR Construcciones Navales, Fincantieri, QinetiQ).

As a second criterion, we drop out of the sample all firms with defense revenue below $10 \%$ of their total revenue in 2003 (10 firms: General Electric, Bechtel Group, Mitsubishi Electric, Electronic Data Systems, NEC, Ericsson, Toshiba, Komatsu, Ishikawajima-Harima Heavy Industries and Fuji Heavy Industries). After these exclusions, 79 firms were left in the sample.

We use daily stock returns for each firm. The stock prices series are extracted from Datastream (Thomson Financial). After dropping 21 firms $^{2}$ for which no data was available in Datastream, we were left with the 58 firms that constitute our sample. The time period extends from January 1995 to May 2005. Stock prices are adjusted for dividend payouts and stock splits. The 58 firms are listed in Appendix 1. ${ }^{3}$

\footnotetext{
${ }^{1}$ The biggest firm overall in the ranking is General Electric but its defense revenue only accounts for $2.3 \%$ of its total revenue (USD 134 billion).

${ }^{2}$ Hindustan Aeronautics, Korea Aerospace Industries, Engineered Support Systems, MITRE, Denel, The Aerospace Corp., ADI, Aerospace Equipment, Battelle, Irkut, Ufa MPO, Tenix Defence, ARINC, Uralvagonzavod, MMPP Salyut, Baltiisky Zavod, Computer Sciences Corp., Science Applications International Corp., Aviation Holding Company Sukhoi and Booz Allen Hamilton.

${ }^{3}$ Additional statistics about stock market capitalization, traded volume, $\mathrm{P} / \mathrm{E}$ ratio, book-to-market ratio, etc. extracted from Datastream are available upon request.
} 
Table 1. Descriptive statistics

\begin{tabular}{lcccccc}
\hline \hline \multirow{2}{*}{2003} & \multicolumn{3}{c}{ Initial sample } & \multicolumn{3}{c}{ Final sample } \\
(USD millions) & \multicolumn{2}{c}{ (World Top 100 Defense) } & \multicolumn{2}{c}{ (58 publicly listed defense firms) } \\
& $\begin{array}{c}\text { Total } \\
\text { revenue }\end{array}$ & $\begin{array}{l}\text { Defense } \\
\text { revenue }\end{array}$ & $\%$ & $\begin{array}{c}\text { Total } \\
\text { revenue }\end{array}$ & $\begin{array}{c}\text { Defense } \\
\text { revenue }\end{array}$ & $\%$ \\
\hline Minimum & 310 & 260 & 1 & 460 & 272 & 10 \\
Maximum & 134,200 & 30,097 & 100 & 50,500 & 30,097 & 100 \\
Median & 1,968 & 843 & 51 & 2,433 & 1,111 & 58 \\
Mean & 8,575 & 2,458 & 53 & 7,715 & 3,591 & 60 \\
Standard Error & 16,926 & 5,040 & 32 & 10,752 & 4,363 & 26 \\
\hline \hline
\end{tabular}

\section{Methodology}

We present in this section the general methodology of event studies, then the methodology we adopted, focusing on the distinguishing features of our methodology compared to the traditional one.

\subsection{The general methodology of event studies}

The event study methodology is designed to investigate the reaction of the stock market to news or events concerning a firm, an industry or the whole stock market. The basic underpinning of event studies is the efficient market hypothesis (Fama, 1969), which states that as new information becomes available, it is fully taken into account by investors assessing its current and future impact. Under this hypothesis, stock price changes reflect the discounted value of current and future firm performance. Investors' reaction to a given information release (i.e. a news item) can be measured simply by comparing the observed return during a given time period following the event to the expected return in absence of any event; this difference is called the "abnormal return". If investors react (un)favorably to an event, we would expect (negative) positive significant abnormal stock returns. The strength of 
the event study approach is that it is based on the overall assessment of many investors who quickly process all available information in assessing each firm's market value.

Event study methodology has been widely used in finance (see Brown and Warner, 1985; MacKinlay, 1997; Binder, 1998; Kothari and Warner, 2005). Kothari and Warner (2005) list more than 565 event studies published between 1974 and 2000 in the 5 leading finance journals. The number of papers per year increased in the 1980's and has been quite stable since then. For instance, numerous event studies have been devoted to the impact of shares distributions, earnings and/or dividends, mergers, technological accidents, massive layoffs, etc.

Two critical points in the conduct of an event-study are: the estimation of the expected (theoretical) returns and the selection of the events to be studied. First, one must use a model to estimate the expected returns for each stock. In general, the market model is chosen. Second, one must be careful in defining the nature of the event and the precise date of the information release, which is not necessarily the event date (Henderson, 1990). Moreover, the choice of news source is important: Glascock, Davidson and Henderson (1987) show that the Wall Street Journal, often chosen as the news source, does not publish all the news, and publishes some news with a delay, introducing a bias in the sample. Practically-speaking, a lack of precision in dating and selecting the events can cause a loss of power of the statistical tests of significance (Brown and Warner, 1980, 1985).

Since we want to identify the main type of news driving stock price changes and assess the relative importance of this news, the traditional event study methodology is not really suitable, because we cannot content ourselves with one a priori defined type of news. Following the methodology introduced by Thompson, Olsen and Dietrich $(1987)^{4}$, with twelve a priori categories of news, would not be consistent with our goals: with such a priori defined categories, there is no way of being sure to capture the news events that are the strongest stock price movers; furthermore, the results would always be conditional on the initial definition of the categories ${ }^{5}$.

\footnotetext{
${ }^{4}$ Same or similar methodology is adopted by Pritamani and Singal (2001) with seven news. See also Cutler, Poterba and Summers (1989).

${ }^{5}$ Another concern with this approach is that the authors consider raw returns instead of abnormal returns, that is they do not take into account the general trend on the market and the idiosyncratic risk of each stock.
} 


\subsection{A time varying GARCH event study}

In this paper, we adopt an alternative methodology to the traditional one. Instead of conducting our study with an a priori defined type of event, we investigate all the abnormal returns for each stock during the time period under study. We then search for explanations of these abnormal returns. The advantages of this methodology are that we can really investigate what kind of news is really driving the stock price movements, without any prior framework, and that we are free from selection bias in the definition of events. We follow a two-step estimation strategy. We first perform a set of rolling regressions to estimate expected returns for each stock and each trading day from 1995 to 2005 and compute the daily abnormal returns. Then, we select the dates where the daily abnormal returns are statistically significant and we search for plausible explanations.

Here we closely follow Ryan and Taffler (2004) (see also Lardic and Mignon, 2002), but we improve their methodology in two ways: we take into account conditional heteroskedasticity, and we implement time-varying estimations.

\section{A market model with conditional heteroskedasticity}

For each of the 58 firms of our sample, we apply the following method over a (maximum) time period of 10 years (1995 to 2005). We implement a methodology that incorporates timevarying market risk and time-varying heteroskedastic error structure into the baseline market model. For any stock, the market model is estimated on a 120 -day window:

$$
R_{i, j}=\square_{i}+\square_{i} R_{m, j}+\square_{i, j} \quad \text { with } j=-120, \ldots,-1
$$

with $R_{i, j}$ the daily stock return of stock $i$ at time $j, R_{m, j}$ the daily market return at time $j, \square_{i}$ and $\square_{i}$ two parameters to be estimated, and $\square_{i, j}$ the residuals, with a zero mean normal distribution and a $\square_{i, j}^{2}$ variance.

The parameters of the market model are usually estimated using OLS regression. These parameters are then used to calculate abnormal returns. But such a method is based on strong statistical assumptions. In particular, it is assumed that the error term $\square_{i, j}$ is temporally uncorrelated and follows a normal distribution with constant variance. However, there is 
overwhelming evidence that these assumptions are not fulfilled: individual stocks are correlated, with large returns (whatever sign) that tend to be followed by further large returns (of either sign) and variance is heteroskedastic (Henderson, 1990; Campbell, Lo and MacKinlay, 1997). Brown and Warner $(1980,1985)$ point out that the power of tests can be improved by appropriately modeling the volatility process. A number of studies (Boehmer, Musumeci, and Poulsen, 1991; De Jong, Kemna, and Kloek, 1992; Brockett, Chen and Garven, 1999; Savickas, 2003; Harrington and Shrider, 2006) have proposed event study methodologies that extend the basic market model methodology to include either ARCH or GARCH structures (Bollerslev, 1986).

In this study, a $\operatorname{GARCH}(1,1)$ framework is used to estimate the market model (i.e. we assume a non-constant variance during the time period under review). In this framework, equation (1) is the mean equation, and the conditional variance equation is:

$$
\square_{i, j}^{2}=a_{i}+b_{i} \square_{i, j \square 1}^{2}+c_{i} \square_{i, j \square 1}^{2}
$$

with $\square_{i, j \square}^{2}$ the lagged squared residuals of equation (1) and $a, b$ and $c$ three parameters which are estimated by the maximum likelihood method.

\section{The rolling regression routine}

The aim of the paper is to examine information events that drive significant stock price changes for the defense industry. Prior studies usually assume that the beta is constant over time ${ }^{6}$ However, the beta may change after significant price movements. Accordingly, we adopt a time-varying coefficient market model. More precisely, for each firm in our sample, we compute 120-day rolling regression estimates, incremented by 1 day. That is, for each firm, the market model parameters are estimated on a time-varying window $j=[-120 ;-1]$ for each day $t$.

$$
R_{i, t+j}=\square_{i, t}+\square_{i, t} R_{m, t+j}+\square_{i, t+j}
$$

\footnotetext{
${ }^{6}$ For instance, Ryan and Taffler (2004) used betas from the London Business School Risk Measurement Service which are computed on the previous calendar year, i.e. before the beginning of their sample.
} 
We obtain a maximum of 2,575 estimates per firm (2,695 returns between January 1995 and May 2005 minus 120 days), that is, about 125,000 estimates in total.

For the whole time period, the average return of firms included in the sample is above the average market return: in annualized figures, nearly $12 \%$ against only $6 \%$ for the market (see Appendix 2). The highest return rate is for United Defense Industries $(+45.5 \%$ per year on average, between 2001 and 2005). At the other extreme, the market capitalizations of Kawasaki Heavy Industries, Mitsubishi Heavy, Silicon Graphics and Bearing Point decreased over the time period. For the whole time period, the annual average volatility, measured by a $\operatorname{GARCH}(1,1)$ process, is at a conventional level, from $3.50 \%$ for Ultra Electronics to $17.5 \%$ for Silicon Graphics. The average systematic risk is 0.66 , from 0.16 for VT Group to 1.37 for Bearing Point.

\section{The abnormal returns}

Once the parameters of both equations are estimated, one can obtain the expected or theoretical return for each stock $i$ on day $t$, just by using the following equation:

$$
\hat{R}_{i, t}=\square_{i, t}+\hat{\square}_{i, t} R_{m, t}
$$

and, as usual, the abnormal returns at time $t$ are simply the difference between the expected and the observed returns at this time:

$$
\hat{A R} R_{i, t}=\hat{R}_{i, t} \square \square_{i, t} \square \hat{D}_{i, t} R_{m, t}
$$

In this study, since our ultimate goal is to determine the events that drive stock prices in the defense industry, we are not interested in cumulative abnormal returns (CAR) or average abnormal returns (AAR). But we still have to compute the $t$-stat indicating the significance of each daily abnormal return. As we use a GARCH structure, the $t$-stat takes into account the fact that the variance is not constant:

$$
t \square s t a t_{i, t}=\frac{A R_{i, t}}{\square_{i, t}}
$$


Under the null hypothesis that the abnormal return is zero, this statistic is distributed as the normal standard distribution.

\subsection{Matching of largest abnormal returns to news}

To explore the information events which drive stock market capitalization in the defense industry, we have to assign abnormal returns to one information release. In this paper, we adopt a conservative approach as we match the 10 largest significant price changes ( 5 up and 5 down) for each stock to news events. One can interpret our objective as to find, for each abnormal return, a related piece of news or announcement likely to explain it.

The information source we used is the Lexis-Nexis database (Reed-Elsevier), a database of more than 11,000 newspapers and magazines, including some specifically devoted to the defense industry (e.g. Aerospace Daily, Air Force Times, Aviation Week's Homeland Security \& Defense, Avionics, Defense Daily, Defense News, Defense and Security, IAC Aerospace \& Defense, Inside the Pentagon, etc.) and all the major world financial newspapers (Wall Street Journal, Financial Times, etc.). ${ }^{7}$ Following an usual procedure, we constrain our investigations to an event window of 10 days centered on the day of the stock price movement to avoid potential data mining. To ensure an unbiased and reliable matching, we first collect all the news concerning the firm under review for the relevant time period. Then we analyze the information, searching for all the possible explanations of the stock price movement and excluding general information, such as business history, interviews with the managers in which no new information is provided, etc. ${ }^{8}$

The next step was to create homogenous groups of news, assigning each news release to one of the news categories detailed in Appendix 2. This typology was established following prior research (Thomson, Olsen and Dietrich, 1987; Pritamani and Singal, 2001; Ryan and Taffler, 2004) and extended to specific areas closely related to the defense industry (e.g. geopolitical events, military budget changes, etc.). When a news release does not correspond to any existing category, a new category was added to the typology. At the end, there are seventeen

\footnotetext{
${ }^{7}$ The sample considered by Ryan and Taffler (2004) consists of all industrial companies in the FTSE 100 and FTSE Mid-250 indices (excluding financials) for the two-year period ( $1^{\text {st }}$ January, 1994 to $31^{\text {st }}$ December, 1995$)$. They use the following data sources: the London Stock Exchange Regulatory News Service, the Financial Times, and McCarthy Information.

${ }^{8}$ Complete results of the matching process are available on request.
} 
news categories including: "information available but non-related to the defense industry" (e.g. Saab announces an increase in its car sales) plus a "no information available" category. ${ }^{9}$

\section{Empirical results}

Prior to examining what type of news influences stock prices in the defense industry, we first have to investigate the overall distribution of the significant abnormal returns. In a second step, we elaborate a broad typology where we distinguish between i) rumors, announcements and unforeseeable events; ii) general and firm-related events; iii) financial and industrial news. In a third step, we refine the previous typology and use a seventeen item classification to underline the respective relevance of bids, strategic alliances between firms, and company restructuring as stock movers. Finally, we focus on the impact of the September 11 terrorist attacks on defense firms.

\subsection{Overall analysis of significant abnormal returns}

Table 2 gives some descriptive statistics about the distribution of all daily abnormal returns. We consider three panels: i) abnormal returns significant at 5\%, ii) abnormal returns significant at $1 \%$, and iii) the five largest abnormal increases and the five largest abnormal decreases for each firm.

For the whole sample, 7,530 daily abnormal returns are significant at 5\% and 3,230 at $1 \%{ }^{10}$ Of these 7,530 significant abnormal returns, $56 \%$ are positive, $25 \%$ are below $-4.46 \%$ and $25 \%$ are above $5.26 \%$. We obtain approximately the same proportions with the abnormal returns significant at $1 \%$. The distribution of the event sample exhibits a characteristic twopeak distribution (see figure 1), since we drop out of the sample all the abnormal returns nonsignificant at $5 \%$.

\footnotetext{
${ }^{9}$ This matching between a news release and the category that describes it best was done by hand, by the two authors, independently. In more than $94 \%$ of the cases, the two researchers chose the same news category. Nevertheless, the choices for the remaining $6 \%$ of cases were not the same. For all these cases, an agreement was found after meeting and discussion between the two researchers; see also Ryan and Taffler (2004). The results detailed and discussed in section 4 remain unchanged if we exclude these cases from the sample.

${ }^{10}$ For a total number of observations (number of firms times number of days in the time period) of approximately 150,000 . This means that about $5 \%$ of the abnormal returns are significant at $5 \%$ and $2 \%$ are significant at $1 \%$.
} 
Table 2. Frequency and distribution of significant abnormal returns, 1995-2005

\begin{tabular}{|c|c|c|c|c|c|c|c|c|c|c|}
\hline & \multirow[t]{2}{*}{$\begin{array}{l}\text { Observed } \\
\text { return }\end{array}$} & \multicolumn{3}{|c|}{$\begin{array}{c}\text { Abnormal returns } \\
\text { significant at the 5\% level }\end{array}$} & \multicolumn{3}{|c|}{$\begin{array}{c}\text { Abnormal returns } \\
\text { significant at the } 1 \% \text { level }\end{array}$} & \multicolumn{3}{|c|}{ Largest abnormal returns } \\
\hline & & all & up & down & all & up & down & all & up & down \\
\hline Mean & $0.70 \%$ & $0.6 \%$ & $5.8 \%$ & $-5.9 \%$ & $0.8 \%$ & $7.3 \%$ & $-7.8 \%$ & $-0.8 \%$ & $12.1 \%$ & $-13.8 \%$ \\
\hline Minimum & $-77.7 \%$ & $-75.6 \%$ & $0.5 \%$ & $-75.6 \%$ & $-75.6 \%$ & $0.7 \%$ & $-75.6 \%$ & $-75.60 \%$ & $2.6 \%$ & $-75.60 \%$ \\
\hline First quart. & $-4.4 \%$ & $-4.5 \%$ & $3.7 \%$ & $-6.7 \%$ & $-5.7 \%$ & $4.6 \%$ & $-9.0 \%$ & $-11.5 \%$ & $8.0 \%$ & $-14.9 \%$ \\
\hline Median & $2.7 \%$ & $2.9 \%$ & $4.9 \%$ & $-4.8 \%$ & $3.8 \%$ & $6.3 \%$ & $-6.3 \%$ & $-0.4 \%$ & $10.4 \%$ & $-11.5 \%$ \\
\hline Third quart. & $5.4 \%$ & $5.3 \%$ & $6.9 \%$ & $-3.6 \%$ & $6.8 \%$ & $8.6 \%$ & $-4.6 \%$ & $10.4 \%$ & $13.8 \%$ & $-8.5 \%$ \\
\hline Maximum & $56.7 \%$ & $56.8 \%$ & $56.8 \%$ & $-0.6 \%$ & $56.8 \%$ & $56.8 \%$ & $-1.0 \%$ & $56.8 \%$ & $56.8 \%$ & $-3.5 \%$ \\
\hline Nb. & & 7,530 & 4,211 & 3,319 & 3,230 & 1,845 & 1,385 & 580 & 290 & 290 \\
\hline$\%$ & & $100 \%$ & $56 \%$ & $44 \%$ & $100 \%$ & $57 \%$ & $43 \%$ & $100 \%$ & $50 \%$ & $50 \%$ \\
\hline By firm (avg.) & & 121 & 68 & 54 & 52 & 30 & 22 & 10 & 5 & 5 \\
\hline
\end{tabular}

Note: Abnormal returns are computed given the market model parameters which are estimated with conditional heteroskedasticity $\mathrm{GARCH}(1,1)$ by the maximum likelihood method through the estimation window $[-120 ;-1]$ in event time. Largest abnormal returns are defined as the five largest abnormal increases and the five largest abnormal decreases for each firm. The sample contains 58 publicly listed firms included in the "World Top 100 Defense firms". The time period extends from January 1995 to May 2005. 
Figure 1. Significant abnormal returns distribution, all sample, 1995-2005

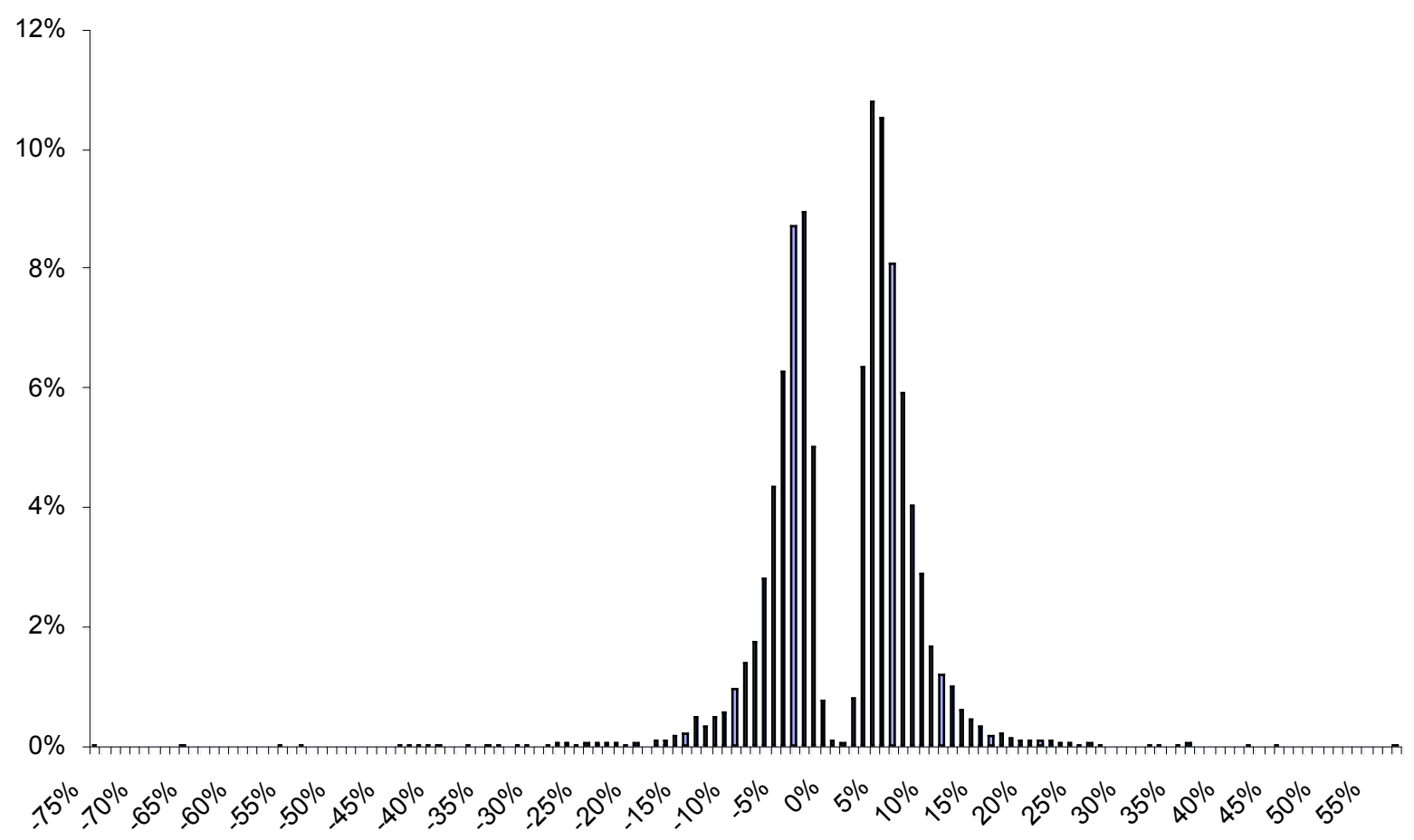

Note: All significant abnormal returns at the $5 \%$ level in our sample. Abnormal returns are computed given the market model parameters which are estimated with conditional heteroskedasticity $\operatorname{GARCH}(1,1)$ by the maximum likelihood method through the estimation window $[-120 ;-1]$ in event time. The sample contains 58 publicly listed firms included in the "World Top 100 Defense firms". The time period extends from January 1995 to May 2005.

Concerning the distribution over time, (cf. Figure 2), quite surprisingly, 2001 is not the year with the highest number of significant abnormal returns. But the concentration of the events is consistent with common sense, with 83 abnormal returns in the 10-day period following the 9-11 events (nearly $10 \%$ of all the 2001 abnormal returns). The other terrorist attacks are not followed by such a high number of abnormal returns: in the 10 days following the terrorist attack on Madrid train stations (March 2004), there are 12 abnormal returns, less than the average on the year. 
Figure 2. Significant abnormal return distribution by year, 1995-2005

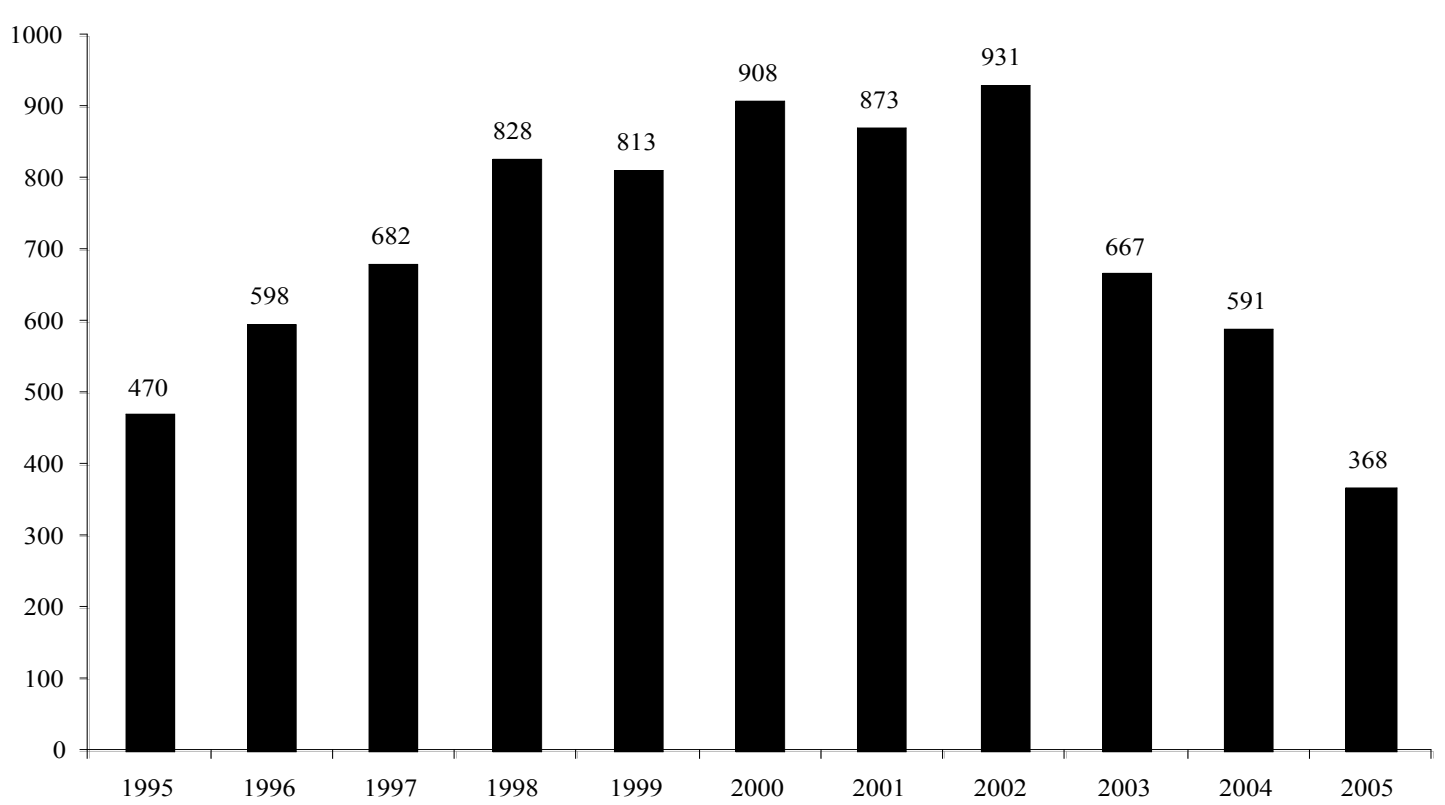

Note: Number of significant abnormal returns at the 5\% level in our sample for each year. Abnormal returns are computed given the market model parameters which are estimated with conditional heteroskedasticity $\operatorname{GARCH}(1,1)$ by the maximum likelihood method through the estimation window $[-120 ;-1]$ in event time. The sample contains 58 publicly listed firms included in the "World Top 100 Defense firms". The time period extends from January 1995 to May 2005. For 2005, the observed figure for the first half of the year is transformed into an annual figure.

We focus in the following analysis on the five largest abnormal increases and five largest abnormal decreases of the stock price for each firm. This focus was made in order to avoid the data mining problem which would arise if we tried to match each abnormal return with an event. With our restrictive definition of the sample (580 events: 10 events for 58 firms), we are almost certain that these large stock price movements have an explanation, that they are not just noise.

\subsection{What type of news influence stock prices?}

Table 3 summarizes the results of the matching process between the largest abnormal returns and news. First, we present the percentage of the largest abnormal returns related to publicly available news. Then, we consider three criteria: Is the news a rumor, an announcement or an unforeseeable event? Is the news general or firm-related? Is the news related to financial or industrial concerns? In the following subsection we refine our typology, breaking it down into seventeen categories. 
Table 3. What type of news causes a stock price change?

\begin{tabular}{lcccc}
\hline \hline & All events & Good news & Bad news & Good minus Bad \\
\hline No news & $29.9 \%$ & $25.9 \%$ & $33.8 \%$ & $-7.9 \%^{* *}{ }^{* *}$ \\
News & $70.1 \%$ & $74.1 \%$ & $66.2 \%$ & $7.9 \%^{* *}$ \\
Of which... & & & \\
$\quad$ Rumor & $11.3 \%$ & $12.5 \%$ & $9.9 \%$ & $2.6 \%$ \\
$\quad$ Announcement or news & $80.7 \%$ & $81.7 \%$ & $79.9 \%$ & $1.8 \%^{*}$ \\
$\quad$ Unforeseeable event & $8.0 \%$ & $5.8 \%$ & $10.2 \%$ & $-4.4 \%^{*}$ \\
\hline Of which... & & & & \\
General news & $11.1 \%$ & $9.2 \%$ & $13.0 \%$ & $-3.8 \%$ \\
$\quad$ Firm-related news & $88.9 \%$ & $90.8 \%$ & $87.0 \%$ & $3.8 \%$ \\
\hline Of which... & & & & \\
Financial news & $60.2 \%$ & $52.6 \%$ & $68.8 \%$ & $-16.2 \%{ }^{* *}$ \\
Industrial news & $23.8 \%$ & $33.0 \%$ & $13.5 \%$ & $19.5 \%{ }^{* *}$ \\
$\quad$ Other news & $16.0 \%$ & $14.4 \%$ & $17.7 \%$ & $-3.3 \%$ \\
\hline \hline
\end{tabular}

In columns 2, 3 and 4 we give the percentage of total abnormal returns the category represents. In the last column, we use the following $Z$-statistics for the difference between two proportions:

$\mathrm{Z}=\left(\mathrm{p}_{1}-\mathrm{p}_{2}\right) / \quad\left[\mathrm{p}_{1}\left(1-\mathrm{p}_{1}\right) / \mathrm{N}_{1}+\mathrm{p}_{2}\left(1-\mathrm{p}_{2}\right) / \mathrm{N}_{2}\right]$

** and $*$ indicate significance at the $1 \%$ and the $5 \%$ level.

To what extent does publicly available news drive abnormal returns? Despite our conservative approach in the selection of abnormal returns, it is striking to note that when analyzing the type of news driving the largest significant stock price changes, the ratio of significant abnormal returns not related to news is very high: nearly a third of all stock price changes remain unexplained. Our results are in line with those of Ryan and Taffler (2004): in their study, $35 \%$ of the stock price movements are not related to firm-specific news, this figure increasing to $45 \%$ for the smallest firms of their sample (firms listed in the FTSEMid250). Two alternative explanations can be proposed to explain the high ratio of significant abnormal returns not related to news. First, one could argue that our methodological approach does not allow us to capture all the pertinent sources of publicly available information about defense products, costs or prospects. It is a well-known fact that disclosure of information is directly related to firm size (Grant, 1980; Atiase, 1985). Indeed, some firms included in our sample are quite small. But, the number of newspapers and other sources of information included in the Lexis-Nexis database seems to invalidate this explanation. Second, given the 
size of the significant abnormal returns (the five largest increases and the five largest decreases), it is reasonable to assume the existence of non-publicly available information. The higher percentage of "no news" for the largest negative abnormal returns relative to the largest positive abnormal returns (34\% against $26 \%$, a difference that is statistically significant at the $1 \%$ level) is also puzzling.

Is the news a rumor, an announcement or an unforeseeable event? In $11 \%$ of all the largest abnormal returns that can be related to an information release, the information is provided in the conditional mode, i.e. subject to confirmation, not verified or affirmed. This figure, together with the high percentage of unexplained stock price changes, makes it reasonable to assume the existence of private information able to influence stock prices. We also note that $8 \%$ of the events are totally unforeseeable, such as the terrorist attacks. Given our sample time period (1995-2005), it is not surprising that negative unforeseeable events are significantly more frequent than positive ones $(10 \%$ against $6 \%)$.

Is the news general or firm-related? Turning to the general characteristics of news influencing the stock prices of defense industry firms, we observe that firm-related news is far more frequent (nine news items out of ten) than news related to the defense industry or to geopolitical or macroeconomic matters (one out of ten).

Is the news related to financial or industrial concerns? More interesting is the predominance of finance-related news (60\%) over industry-related news $(24 \%)$. This result is not the consequence of an initial bias in the news sample because, for a particular firm during a given month, the number of news items related to financial matters is roughly equal to the number related to industrial matters. ${ }^{11}$ One explanation can be given in terms of stock market anticipations. Since industrial news consists essentially of announcements of new contracts, new products or new investments, and given that the time period needed to do a deal or to launch a new product in the defense industry is long, this news is more easily anticipated by stock market investors. More difficult to anticipate are, for instance, earnings revisions, analysts' recommendations, or bid announcements.

\footnotetext{
${ }^{11}$ Given the size of the initial sample of news in Lexis-Nexis, a systematic analysis of this point could not be done. We have only checked the total number of news items related to each firm for a random month during the whole time period under review. Considering all firms, the ratio of financial news to industrial news (neglecting the 'other' news) ranges between 0.70 and 1.5, far below the ratio of 3 between the financial news and the industrial news driving a significant abnormal return (60.2\% against $23.8 \%$ ).
} 


\subsection{The relative importance of earnings, bids and other news releases}

We analyze in this subsection the precise type of news driving the stock prices of firms in the defense industry (see Table 4). ${ }^{12}$

Table 4. News categories influencing stock price changes

\begin{tabular}{lcccccccc}
\hline & \multicolumn{2}{c}{ All events } & \multicolumn{2}{c}{ Good news } & \multicolumn{2}{c}{ Bad news } & \multicolumn{2}{c}{ Good minus Bad } \\
\hline EARNINGS & 66 & $16.2 \%$ & 32 & $14.7 \%$ & 34 & $18.0 \%$ & $-3.3 \%$ \\
BIDS & 59 & $14.5 \%$ & 41 & $18.8 \%$ & 18 & $9.5 \%$ & $9.3 \%$ & $*$ \\
CONTRACT & 55 & $13.5 \%$ & 48 & $22.0 \%$ & 7 & $3.7 \%$ & $18.3 \%$ & $*$ \\
ANALYST & 48 & $11.8 \%$ & 24 & $11.0 \%$ & 24 & $12.7 \%$ & $-1.7 \%$ & $*$ \\
WARNING & 34 & $8.4 \%$ & 0 & $0.0 \%$ & 34 & $18.0 \%$ & $-18.0 \%$ & $* *$ \\
POLITICS & 33 & $8.1 \%$ & 15 & $6.9 \%$ & 18 & $9.5 \%$ & $-2.6 \%$ \\
PUBSPEND & 22 & $5.4 \%$ & 13 & $6.0 \%$ & 9 & $4.8 \%$ & $1.2 \%$ \\
SHAREDEAL & 21 & $5.2 \%$ & 8 & $3.7 \%$ & 13 & $6.9 \%$ & $-3.2 \%$ \\
PRODUCT & 15 & $3.7 \%$ & 10 & $4.6 \%$ & 5 & $2.6 \%$ & $2.0 \%$ \\
PROSPECT & 11 & $2.7 \%$ & 4 & $1.8 \%$ & 7 & $3.7 \%$ & $-1.9 \%$ \\
FINANCE & 11 & $2.7 \%$ & 6 & $2.8 \%$ & 5 & $2.6 \%$ & $0.2 \%$ \\
MANAG & 10 & $2.5 \%$ & 7 & $3.2 \%$ & 3 & $1.6 \%$ & $1.6 \%$ \\
STRAT & 7 & $1.7 \%$ & 5 & $2.3 \%$ & 2 & $1.1 \%$ & $1.2 \%$ \\
LEGAL & 6 & $1.5 \%$ & 2 & $0.9 \%$ & 4 & $2.1 \%$ & $-1.2 \%$ \\
RESTRUCT & 4 & $1.0 \%$ & 2 & $0.9 \%$ & 2 & $1.1 \%$ & $-0.2 \%$ \\
NODEF & 3 & $0.7 \%$ & 0 & $0.0 \%$ & 3 & $1.6 \%$ & $-1.6 \%$ \\
LABOR & 2 & $0.5 \%$ & 1 & $0.5 \%$ & 1 & $0.5 \%$ & $0.0 \%$ \\
\hline Total & 407 & $100.0 \%$ & 218 & $100.0 \%$ & 189 & $100.0 \%$ & \\
\hline \hline
\end{tabular}

In columns 3, 5 and 7 we give the percentage the category represents of total abnormal returns. In the last column, we use the following Z-statistics for the difference between two proportions: $Z=\left(p_{1}-p_{2}\right)$ / $\left[\mathrm{p}_{1}\left(1-\mathrm{p}_{1}\right) / \mathrm{N}_{1}+\mathrm{p}_{2}\left(1-\mathrm{p}_{2}\right) / \mathrm{N}_{2}\right]$.** and $*$ indicate significance at the $1 \%$ and the $5 \%$ level.

A parsimonious set of news categories explains a high proportion of all the largest abnormal returns. The first category accounts for $16 \%$ of all the explained price changes. When looking only at the top 4 categories, the figure goes up to $56 \%$. We find, in this top 4 , earnings announcements, bid announcements or published rumors about bids, news related to the conclusion or cancellation of contracts and analysts' recommendations. Our subsequent analysis will mainly focus on the items accounting for more than $5 \%$ of the sample (i.e. the first eight news categories). The figures for the other items are clearly too weak. Moreover, an 
analysis of the differences between the median abnormal return by news category was conducted, but did not produce any clear differences between the various news categories. We therefore do not reproduce these results.

EARNINGS related news releases are the most frequent factor influencing the market value of firms in the defense industry. This category includes all the formal accounting releases, earnings forecast revisions by the firm - excluding earnings forecasts and recommendations published by analysts (ANALYST) and profit warnings (WARNING). If the key role of earnings forecast revisions was expected, it is surprising to note that nearly one third of all the news releases included in the EARNINGS category are formal accounting releases: although they are likely to be anticipated, they have a significant impact on share prices. The key role of profit warnings (WARNING) on share prices can be analyzed in the same way. They represent $18 \%$ of the 'bad news' influencing stock prices, the most frequent type of news related to a decrease in a stock price (and no profit warning is associated with an increase in the stock price, following common sense). This demonstrates how formal accounting releases or forecast revisions have a significant effect on the market's consensus forecasts.

The BIDS category accounts for $14.5 \%$ of the total number of the largest abnormal returns explained by publicly available information (and 70\% of the bid-related news is 'good' news). For the general sample used by Ryan and Taffler (2004) the equivalent figure is only $8.3 \%$. It would appear, then, that bids and take-over related news are more frequently stock price movers in the defense industry than in other industries. This is consistent with the movement of structural change observed over the past 15 years in the defense industry. Besides, for a given firm, the proportion of news releases reporting an announcement or rumor of a bid associated with a significant stock price variation is higher than for every other news category $^{13}$. Note also that private information appears to be prominent in the case of bids.

This category is the one with the highest number of news items reporting speculations or rumors (more than 60\%). And for this category, more than $75 \%$ of the news releases explaining the stock price change are published some days after the change. This proportion is higher than for any other category. The structural changes in the defense industry, analyzed from the investor's point of view, are mainly the work of bids. Company restructurings

\footnotetext{
${ }^{12}$ News classification and examples are provided in Appendix 3.

${ }^{13}$ On average, a significant stock price variation is associated with more than $40 \%$ of the news items relating to a bid announcement or rumor.
} 
(RESTRUCT) or labor force reductions (LABOR) each account for less than $1 \%$ of the sample.

Industry-related news is not very frequent in our sample. CONTRACT, that is announcements or speculation about new contracts or cancellation of existing contracts, represents $13 \%$ of the total number of cases. PRODUCT, that is news related to new products and expectations regarding product launch or recall, accounts for less than $4 \%$. One should note, however, that these categories do not appear in the principal news categories in Ryan and Taffler (2004), as their respective weight is under $4.7 \%$. Accordingly, we can say that news about contracts and new products has a larger influence on stock prices in the defense industry than in other industries. A plausible explanation is simply that in the defense industry, only a few contracts are concluded each year, each of them worth several USD millions.

The ANALYST category (recommendations and earnings forecasts that do not occur simultaneously with any other news release) is the fourth market mover category. Analysts contribute to the efficiency of stock markets by compiling, analyzing and processing (public or private) information. As the ANALYST category accounts for nearly $12 \%$ of the news in our sample, our results confirm that analyst recommendations add value and convey new information to the market. There is no clear difference here in the value added by analysts for investors in the defense industry compared to other industries, as Ryan and Taffler (2004) report a figure of $10.5 \%$ with their diversified sample of firms with a comparable definition of the category.

Geopolitical and macroeconomic events (POLITICS), probably due to a strong unforeseeable dimension and the choice of our time period, have a clear effect on defense industry firms. Among the main geopolitical events listed, we find the September 11 terrorist attacks (see next sub-section), the concerns about the war in Iraq and in Afghanistan, and oil price related news. News related to public spending (PUBSPEND) also play a significant role in significant abnormal stock price changes. A skeptical reader may dismiss these results as simply confirming the obvious, given the key role of the government as a customer of the defense industry. We, in contrast, consider this result an important specific feature of the defense industry. Ryan and Taffler (2004), with their heterogeneous sample of firms, do not even mention this category, probably because they consider that firm-specific news are the main market movers. Our results show that macroeconomic and geopolitical news cannot be neglected for understanding market price changes in the defense industry. 
The last category which accounts for more than $5 \%$ of our sample is SHAREDEAL. This category groups together all information releases related to a significantly larger than average trading volume in a firm's stock that is not related to a bid: for instance, the sale of all the shares owned by the dominant shareholder, or director share dealing. Comparing these results with those of Ryan and Taffler (2004), we see that this category is less important for defense firms than for other firms: $5.2 \%$ against $15.3 \%$ ( $8.5 \%$ for director share dealing $+6.8 \%$ for other share dealings).

\subsection{What is the effect of September 11?}

Only two firms, out of our sample of 54 top firms in the defense industry ${ }^{14}$, were not affected by the September 2001 terrorist attacks: Alvis, a British company ranked 62 in 2003 by Defense News, and Kongsberg Gruppen, a Norwegian company ranked 78 in 2003. For all the others, we find significant abnormal returns (either positive or negative) at the 5\% level around the date of the terrorist attacks. ${ }^{15}$ Table 5 presents these results.

Almost all firms in the defense industry reacted significantly to the terrorist attacks, but the reaction is very different from one firm to another. Indeed, the reaction to the terrorist attacks was positive for half of the 52 firms, and negative for the other half. For the 52 firms, abnormal returns are large: the mean daily abnormal return is $+14 \%$ for the former and $-9 \%$ for the latter (Panel A). These results illustrate the widespread co-existence of civil and military activities. No one would be surprised to observe that Boeing and EADS (Airbus), for instance, incurred a loss in their stock market capitalization. Moreover, we observe a strong correlation between abnormal returns and the percentage of revenue from defense. When this percentage is lower than $49 \%$; the mean daily abnormal return is $-3 \%$ while for the other half, the mean daily abnormal return is $8 \%$ (Panel $\mathrm{B})$.

\footnotetext{
${ }^{14}$ The stock price time-series extracted from Datastream for Anteon, ManTech International, United Defense Industry, and Washington Group International begins after September 2001.

${ }^{15}$ As we compute daily abnormal returns, some firms exhibit several significant abnormal returns in September 2001. For each firm, we only consider the first significant daily abnormal return following the terrorist attacks. Daily abnormal returns following September 11, 2001 are provided in Appendix 4. For more details, see Capelle-Blancard, Couderc and Stachowiak (2006).
} 
Table 5. Daily significant abnormal returns following September 11, 2001

\begin{tabular}{|c|c|c|c|c|}
\hline & $\begin{array}{l}\text { Daily abnormal } \\
\text { returns }\end{array}$ & $\begin{array}{l}\text { Revenue from } \\
\text { Defense }\end{array}$ & $\begin{array}{l}\text { Daily abnormal } \\
\text { returns }\end{array}$ & $\begin{array}{l}\text { Revenue from } \\
\text { Defense }\end{array}$ \\
\hline Panel A & \multicolumn{2}{|c|}{ Positive impact } & \multicolumn{2}{|c|}{ Negative impact } \\
\hline \# of firms & \multicolumn{2}{|c|}{26} & \multicolumn{2}{|c|}{26} \\
\hline Mean & $14 \%$ & $62 \%$ & $-9 \%$ & $37 \%$ \\
\hline Median & $11 \%$ & $63 \%$ & $-7 \%$ & $32 \%$ \\
\hline SD & $8 \%$ & $24 \%$ & $6 \%$ & $21 \%$ \\
\hline Min & $3 \%$ & $12 \%$ & $-28 \%$ & $10 \%$ \\
\hline Max & $35 \%$ & $95 \%$ & $-3 \%$ & $80 \%$ \\
\hline Panel B & \multicolumn{2}{|c|}{ Revenue from Defense $<49 \%$} & \multicolumn{2}{|c|}{ Revenue from Defense $\geq 49 \%$} \\
\hline \# of firms & \multicolumn{2}{|c|}{26} & \multicolumn{2}{|c|}{26} \\
\hline Mean & $-3 \%$ & $28 \%$ & $8 \%$ & $71 \%$ \\
\hline Median & $-5 \%$ & $26 \%$ & $8 \%$ & $71 \%$ \\
\hline SD & $12 \%$ & $12 \%$ & $14 \%$ & $16 \%$ \\
\hline Min & $-28 \%$ & $10 \%$ & $-16 \%$ & $49 \%$ \\
\hline Max & $22 \%$ & $46 \%$ & $35 \%$ & $95 \%$ \\
\hline Panel C & \multicolumn{2}{|c|}{ US + Canada } & \multicolumn{2}{|c|}{ Other countries } \\
\hline \# of firms & \multicolumn{2}{|c|}{28} & \multicolumn{2}{|c|}{24} \\
\hline Mean & $6 \%$ & $51 \%$ & $-2 \%$ & $48 \%$ \\
\hline Median & $10 \%$ & $48 \%$ & $-4 \%$ & $48 \%$ \\
\hline SD & $16 \%$ & $27 \%$ & $7 \%$ & $25 \%$ \\
\hline Min & $-28 \%$ & $11 \%$ & $-20 \%$ & $10 \%$ \\
\hline Max & $35 \%$ & $95 \%$ & $9 \%$ & $94 \%$ \\
\hline
\end{tabular}

Another interesting point is the stock market reaction of North American firms compared to the others (Panel C). The mean daily abnormal return is $6 \%$ for the US and Canadian firms against $-2 \%$ for the others (the difference between the median is even larger). ${ }^{16}$ Chen and Siems (2004) show that the decline in the U.S. and Canadian capital market, though significantly different from zero, was not as great as eight of the other nine largest world markets. ${ }^{17}$ They attribute this result to the depth of the North American stock market, the calming effect of the closing of the U.S. capital markets until September 17 2001, and the stability of the banking and financial sector. Another explanation could be the positive impact of the terrorist attacks on several US firms which might benefit more from the new geopolitical context.

\footnotetext{
${ }^{16}$ Note that this result cannot be attributed to a different percentage of revenue from defense.

${ }^{17}$ For an examination of the impact of terrorism on stock markets, see also Karolyi and Martell (2005).
} 


\section{Conclusion}

This study seeks to determine whether defense firms' largest stock price changes are driven by macroeconomic, microeconomic, or non-economic events, or just noise. The distinctive features of the defense industry motivate such a study.

The traditional method of event studies is limited by the necessary a priori definition of the categories of events. Therefore, we adopt an alternative methodology to explore the relationship between information events and stock price changes. We first identify, for a given firm, the statistically significant abnormal returns over the time period. Secondly, we look for information releases likely to cause such abnormal returns. Moreover, we consider time-varying beta estimates and a GARCH process to model the volatility. Our sample consists of the 58 largest listed firms in the defense industry. For each firm, we focus mainly on the 10 largest significant abnormal returns (5 up and 5 down) over the 1995-2005 time period.

We show in this paper that the news driving the market value of defense firms is roughly the same as for other industries. Formal accounting releases (earnings announcements, profit warnings, etc.) play a key role in explaining the largest stock price changes. There is also some evidence in favor of the existence of transactions motivated by private information, since one third of the largest stock price changes are not related to an information release. Nevertheless, the defense industry presents some specific features that distinguish it from other industries. Firstly, the most striking difference is probably the key role played by bid announcements or rumors, which account for nearly $15 \%$ of the stock prices changes. Secondly, public military spending plays a key role as a driving force of stock prices in the defense industry. This role is probably due to the relationship between public spending and the number of contracts to be concluded with the defense industry. And the contract-related news are an important stock price mover. Thirdly, the geopolitical context and geopolitical events clearly influence stock prices of the defense industry in a specific way. In fact, nearly all the firms react to geopolitical events, but the reaction is not uniform. In the September 11 case, the stock price reaction is largely correlated to the relative weight of the military and civilian activities in each firm. 


\section{References}

Asquith P. R., R. F. Brunner and D. W. Mullins, 1983, The gains to bidding firms from merger, Journal of Financial Economics, 11(1-4), 121-140.

Atiase R. K., 1985, Predisclosure Information, Firm capitalisation, and security price behaviour around earnings announcements, Journal of Accounting Research, 23(1), 21-36.

Binder J. J., 1998, The event study methodology since 1969, Review of Quantitative Finance and Accounting, 11, 111-137.

Boehmer, E., J. Musumeci and A. Poulsen, 1991, Event study methodology under conditions of event induced variance, Journal of Financial Economics, 30, 253-272.

Bollerslev T., 1986, Generalized Autoregressive Conditional Heteroskedasticity, Journal of Econometrics, 31, 307-327.

Brockett P. L., H. M. Chen and J. R. Garven, 1999, A new stochastically flexible event methodology with application to Proposition 103, Insurance: Mathematics and Economics, 25, 197-217.

Brown S. and J. Warner, 1980, Measuring security price performance, Journal of Financial Economics, 8, 205-258.

Brown S. and J. Warner, 1985, Using daily stock returns, the case of event studies, Journal of Financial Economics, 14, 3-31.

Campbell J., A. Lo, and C. MacKinlay, 1997, The econometrics of financial markets, Princeton University Press, New Jersey.

Capelle-Blancard G., N. Couderc and Ch. Stachowiak, 2006, The impact of terrorism on stock market capitalization in the defense industry, Working Paper, University Paris 1 Panthéon-Sorbonne.

Chen A.H. and T.F. Siems, 2004, The effects of terrorism on global capital markets, European Journal of Political Economy, 20, 349-366.

Cutler D., J. Poterba and L. Summers, 1989, What drives stock prices, Journal of Portfolio Management, 15, 4-12.

De Jong, F., A. Kemna, and T. Kloek, 1992, A Contribution to event study methodology with an application to the Dutch stock market, Journal of Banking and Finance, 16, 11-36.

Glascock J. L., W. N. Davidson and G. V. Henderson, 1987, Announcement effects of Moody's bond rating changes on equity returns, Quarterly Journal of Business and Finance, 26, 67-78.

Grant E. B., 1980, Market implications of differential amounts of interim information, Journal of Accounting Research, 18, 255-268.

Harrington S. and D. Shrider, 2006, All events induce variance: Estimating abnormal returns when effects vary across firms, Journal of Financial Quantitative Analysis, forthcoming.

Henderson G. V., 1990, Problems and solutions in conducting event studies, Journal of Risk and Insurance, 57(2), 282-306.

Karolyi G. A. and R. Martell, 2005, Terrorism and the stock market, Working Paper, The Ohio State University.

Kothari S.P. and J.B. Warner, 2005, Econometrics of event studies, in The Handbook of Corporate Finance: Empirical Corporate Finance, B. Espen Eckbo (ed.), Elsevier/North-Holland.

Lardic S. and Mignon V., 2002, Etude d'évènements sur données intraquotidiennes françaises: Les réactions des actionnaires aux annonces, Revue d'Economie Financière, 66, 335-340.

MacKinlay A. C., 1997, Event studies in economics and finance, Journal of Economic Literature, 35, 1, 13-39. 
Markusen A.R. and S.S. Costigan, 1999, Arming the future: A defence industry for the $21^{\text {st }}$ Century, Council on Foreign Relations Press, New York.

Pritamani, M. and V. Singal, 2001, Return predictability following large price changes and information releases, Journal of Banking and Finance, 25, 631-656.

Ryan P. and R.J. Taffler, 2004, Are economically significant stock returns and trading volumes driven by firm-specific news releases?, Journal of Business Finance and Accounting, 31(1-2), 49-82.

Savickas R., 2003, Event-induced volatility and tests for abnormal performance, Journal of Financial Research, 26(2), 165-178.

Susman G. and S. O'Keefe, 1999, The defense industry in the post-Cold War era, Elsevier Science, Oxford.

Thompson R., C. Olsen and J. R. Dietrich, 1987, Attributes of news about firms: an analysis of firmspecific new reported in the wall street journal index, Journal of Accounting Research, 25(2), $245-274$ 


\section{Appendix 1 - Firms included in the sample}

\begin{tabular}{|c|c|c|c|c|c|c|}
\hline $\begin{array}{l}\text { Rank } \\
2003\end{array}$ & Company & Country & $\begin{array}{c}2003 \\
\text { Defense } \\
\text { Revenue } \\
\text { (US\$) }\end{array}$ & $\begin{array}{c}2003 \\
\text { Total } \\
\text { Revenue } \\
\text { (US\$) }\end{array}$ & $\begin{array}{c}2003 \\
\text { Revenue } \\
\text { from } \\
\text { Defense } \\
(\%)\end{array}$ & $\begin{array}{c}\text { End } 2003 \\
\text { FFNOSH } \\
\quad(\%)\end{array}$ \\
\hline 19 & Alliant Techsystems & U.S. & $2,102.0$ & $2,366.0$ & 89 & 43 \\
\hline 62 & Alvis & U.K. & 620.7 & 620.7 & 100 & 49 \\
\hline 44 & Anteon & U.S. & 927.0 & $1,042.0$ & 89 & nd. \\
\hline 63 & Babcock Internat. Group & U.K. & 602.6 & 753.2 & 80 & 44 \\
\hline 4 & BAE Systems & U.K. & $17,159.0$ & $22,359.3$ & 77 & 65 \\
\hline 94 & BearingPoint & U.S. & 328.5 & $3,139.3$ & 11 & 45 \\
\hline 81 & Bharat Electronics & India & 434.2 & 620.2 & 70 & 100 \\
\hline 2 & Boeing & U.S. & $27,360.0$ & $50,500.0$ & 54 & 67 \\
\hline 67 & CACI & U.S. & 536.3 & 843.1 & 64 & 47 \\
\hline 89 & CAE & Canada & 361.6 & 835.9 & 43 & 87 \\
\hline 55 & Cobham & U.K. & 742.7 & $1,480.8$ & 50 & 58 \\
\hline 88 & Cubic & U.S. & 365.1 & 634.0 & 58 & 73 \\
\hline 23 & Dassault Aviation & France & $2,009.1$ & $4,143.8$ & 49 & 50 \\
\hline 43 & DRS Technologies & U.S. & 940.2 & $1,001.3$ & 94 & 38 \\
\hline 8 & EADS & Netherlands & $8,036.5$ & $37,796.6$ & 21 & 100 \\
\hline 82 & EDO & U.S. & 415.0 & 460.7 & 90 & 56 \\
\hline 50 & Elbit Systems & Israel & 848.0 & 898.0 & 94 & 61 \\
\hline 9 & Finmeccanica & Italy & $5,895.5$ & $10,856.8$ & 54 & 67 \\
\hline 6 & General Dynamics & U.S. & $12,782.0$ & $16,617.0$ & 77 & 57 \\
\hline 28 & GKN Group & U.K. & $1,533.7$ & $7,668.7$ & 20 & 69 \\
\hline 34 & Goodrich & U.S. & $1,300.0$ & $4,383.0$ & 30 & 51 \\
\hline 16 & Halliburton & U.S. & $2,700.0$ & $16,271.0$ & 17 & 49 \\
\hline 40 & Harris & U.S. & $1,100.0$ & $2,093.0$ & 53 & 40 \\
\hline 12 & Honeywell & U.S. & $4,200.0$ & $23,100.0$ & 18 & 60 \\
\hline 65 & Indra Sistemas & Spain & 567.3 & $1,232.3$ & 46 & 100 \\
\hline 25 & ITT Industries & U.S. & $1,790.9$ & $5,626.6$ & 32 & 55 \\
\hline 73 & Jacobs Engineering Group & U.S. & 494.0 & $1,884.8$ & 26 & 50 \\
\hline 41 & Kawasaki Heavy Industries & Japan & $1,096.5$ & $10,986.2$ & 10 & 89 \\
\hline 78 & Kongsberg Gruppen & Norway & 456.1 & 991.5 & 46 & 36 \\
\hline 11 & L-3 Communications & U.S. & $4,369.2$ & $5,061.6$ & 86 & 39 \\
\hline 1 & Lockheed Martin & U.S. & $30,097.0$ & $31,824.0$ & 95 & 35 \\
\hline 60 & ManTech International & U.S. & 639.9 & 701.6 & 91 & 33 \\
\hline 95 & Meggitt & U.K. & 314.6 & 715.0 & 44 & 60 \\
\hline 17 & Mitsubishi Heavy Industries & Japan & $2,667.4$ & $22,473.6$ & 12 & 93 \\
\hline 3 & Northrop Grumman & U.S. & $18,700.0$ & $26,200.0$ & 71 & 48 \\
\hline 59 & Oshkosh Truck & U.S. & 657.0 & $1,926.0$ & 34 & 48 \\
\hline 5 & Raytheon & U.S. & $16,896.0$ & $18,100.0$ & 93 & 47 \\
\hline 22 & Rheinmetall DeTec & Germany & $2,014.1$ & $5,334.2$ & 38 & 26 \\
\hline 35 & Rockwell Collins & U.S. & $1,270.0$ & $2,542.0$ & 50 & 60 \\
\hline 18 & Rolls-Royce & U.K. & $2,489.9$ & $9,959.6$ & 25 & 66 \\
\hline 30 & Saab & Sweden & $1,380.0$ & $1,725.0$ & 80 & 52 \\
\hline 96 & Silicon Graphics & U.S. & 314.0 & 962.0 & 33 & 86 \\
\hline 47 & Singapore Tech. Engineer. & Singapore & 903.6 & $1,655.1$ & 55 & 35 \\
\hline 26 & Smiths Industries & U.K. & $1,778.2$ & $4,235.2$ & 42 & 73 \\
\hline 24 & Snecma (Sagem) & France & $1,845.9$ & $8,036.5$ & 23 & 49 \\
\hline 79 & Stewart \& Stevenson & U.S. & 446.0 & $1,175.0$ & 38 & 44 \\
\hline
\end{tabular}




\begin{tabular}{|c|c|c|c|c|c|c|}
\hline $\begin{array}{l}\text { Rank } \\
2003\end{array}$ & Company & Country & $\begin{array}{c}2003 \\
\text { Defense } \\
\text { Revenue } \\
\text { (US\$) }\end{array}$ & $\begin{array}{c}2003 \\
\text { Total } \\
\text { Revenue } \\
\text { (US\$) }\end{array}$ & $\begin{array}{c}2003 \\
\text { Revenue } \\
\text { from } \\
\text { Defense } \\
(\%)\end{array}$ & $\begin{array}{c}\text { End } 2003 \\
\text { FFNOSH } \\
(\%)\end{array}$ \\
\hline 98 & Tadiran Communications & Israel & 272.2 & $1,192.1$ & 23 & nd. \\
\hline 85 & Teledyne Technologies & U.S. & 387.0 & 841.0 & 46 & 58 \\
\hline 27 & Textron & U.S. & $1,600.0$ & $9,859.0$ & 16 & 65 \\
\hline 7 & Thales & France & $8,476.0$ & $13,310.4$ & 64 & 57 \\
\hline 39 & ThyssenKrupp Werften & Germany & $1,110.0$ & $6,152.9$ & 18 & 99 \\
\hline 38 & Titan & U.S. & $1,113.0$ & $1,800.0$ & 62 & 63 \\
\hline 83 & Ultra Electronic Holdings & U.K. & 399.0 & 505.1 & 79 & 48 \\
\hline 21 & United Defense Industries & U.S. & $2,052.6$ & $2,052.6$ & 100 & 57 \\
\hline 10 & United Techologies & U.S. & $5,300.0$ & $31,034.0$ & 17 & 65 \\
\hline 36 & URS & U.S. & $1,230.0$ & $3,200.0$ & 38 & 58 \\
\hline 49 & VT Group & U.K. & 857.8 & $1,225.4$ & 70 & 65 \\
\hline 42 & Washington Group Internat. & U.S. & $1,048.0$ & $2,501.0$ & 42 & 97 \\
\hline
\end{tabular}

Source: 2004 World Top 100 Defense Firms, Defense News Media Group and Datastream (FFNOSH, Free Float Number Of Shares). Figures expressed in USD millions. Currency conversions for non-U.S. firms calculated using prevailing rates at the end of each firm's fiscal year. 


\section{Appendix 2 - Return and market model results}

\begin{tabular}{|c|c|c|c|c|c|c|}
\hline Company & $\begin{array}{l}\text { Time } \\
\text { Period }\end{array}$ & $\begin{array}{l}\text { Market } \\
\text { Index }\end{array}$ & $\hat{\square}$ & $\begin{array}{c}\text { Annualized } \\
\text { price } \\
\text { return }\end{array}$ & $\begin{array}{c}\text { Market } \\
\text { annualized } \\
\text { price } \\
\text { return }\end{array}$ & $\begin{array}{c}\operatorname{GARCH}(1,1) \\
\text { volatility }\end{array}$ \\
\hline Alliant Techsystems & $95-05$ & S\&P 500 & 0.32 & $17.7 \%$ & $9.0 \%$ & $5.6 \%$ \\
\hline Alvis & $95-05$ & FTSE All & 0.20 & $20.5 \%$ & $4.3 \%$ & $6.2 \%$ \\
\hline Anteon & $02-05$ & S\&P 500 & 0.83 & $25.7 \%$ & $-0.1 \%$ & $4.3 \%$ \\
\hline Babcock Intern. Group & $95-05$ & FTSE All & 0.23 & $-0.6 \%$ & $4.3 \%$ & $6.5 \%$ \\
\hline BAE Systems & $95-05$ & FTSE All & 0.81 & $8.4 \%$ & $4.3 \%$ & $7.8 \%$ \\
\hline Bearing Point & $01-05$ & S\&P 500 & 1.37 & $-26.6 \%$ & $-3.1 \%$ & $7.9 \%$ \\
\hline Bharat Electronics & $95-05$ & India BSE & 0.24 & $15.3 \%$ & $5.6 \%$ & $11.7 \%$ \\
\hline Boeing & $95-05$ & S\&P 500 & 0.96 & $9.0 \%$ & $9.0 \%$ & $6.9 \%$ \\
\hline CACI & $95-05$ & S\&P 500 & 0.65 & $26.4 \%$ & $9.0 \%$ & $8.8 \%$ \\
\hline CAE & $95-05$ & S\&P/TSX & 0.71 & $4.4 \%$ & $7.8 \%$ & $8.0 \%$ \\
\hline Cobham & $95-05$ & FTSE All & 0.32 & $13.4 \%$ & $4.3 \%$ & $4.5 \%$ \\
\hline Cubic & $95-05$ & S\&P 500 & 0.57 & $14.9 \%$ & $9.0 \%$ & $8.2 \%$ \\
\hline Dassault Aviation & $95-05$ & SBF 120 & 0.22 & $28.7 \%$ & $7.5 \%$ & $7.3 \%$ \\
\hline DRS Technologies & $95-05$ & S\&P 500 & 0.38 & $24.9 \%$ & $9.0 \%$ & $9.0 \%$ \\
\hline EADS & $00-05$ & SBF 120 & 1.13 & $4.8 \%$ & $-10.4 \%$ & $6.1 \%$ \\
\hline EDO & $95-05$ & S\&P 500 & 0.57 & $22.4 \%$ & $9.0 \%$ & $9.5 \%$ \\
\hline Elbit Systems & $98-05$ & Israel TA 100 & 0.90 & $12.0 \%$ & $11.3 \%$ & $4.8 \%$ \\
\hline Finmeccanica & $95-05$ & Milan Global & 1.11 & $2.9 \%$ & $8.2 \%$ & $8.7 \%$ \\
\hline General Dynamics & $95-05$ & S\&P 500 & 0.59 & $15.8 \%$ & $9.0 \%$ & $5.6 \%$ \\
\hline GKN Group & $95-05$ & FTSE All & 0.95 & $5.5 \%$ & $4.3 \%$ & $6.8 \%$ \\
\hline Goodrich & $95-05$ & S\&P 500 & 0.91 & $6.4 \%$ & $9.0 \%$ & $6.9 \%$ \\
\hline Halliburton & $95-05$ & S\&P 500 & 0.88 & $9.7 \%$ & $9.0 \%$ & $9.9 \%$ \\
\hline Harris & $95-05$ & S\&P 500 & 0.84 & $11.2 \%$ & $9.0 \%$ & $7.2 \%$ \\
\hline Honeywell & $95-05$ & S\&P 500 & 1.18 & $7.2 \%$ & $9.0 \%$ & $7.5 \%$ \\
\hline Indra Sistemas & $95-05$ & Ibex 35 & 0.55 & $29.4 \%$ & $10.5 \%$ & $10.7 \%$ \\
\hline ITT Industries & $95-05$ & S\&P 500 & 0.75 & $16.5 \%$ & $9.0 \%$ & $5.7 \%$ \\
\hline Jacobs Eng. Group & $95-05$ & S\&P 500 & 0.59 & $16.8 \%$ & $9.0 \%$ & $6.1 \%$ \\
\hline Kawasaki Heavy Indus. & $95-05$ & Topix & 1.07 & $-7 . \%$ & $-2.9 \%$ & $9.2 \%$ \\
\hline Kongsberg Gruppen & $95-05$ & Oslo SE & 0.54 & $9.3 \%$ & $7.3 \%$ & $6.1 \%$ \\
\hline L-3 communications & $98-05$ & S\&P 500 & 0.53 & $25.9 \%$ & $0.6 \%$ & $6.3 \%$ \\
\hline Lockheed Martin & $95-05$ & S\&P 500 & 0.48 & $8.6 \%$ & $8.4 \%$ & $6.3 \%$ \\
\hline ManTech International & $02-05$ & S\&P 500 & 0.43 & $10.0 \%$ & $2.2 \%$ & $6.6 \%$ \\
\hline Meggitt & $95-05$ & FTSE All & 0.35 & $13.9 \%$ & $4.3 \%$ & $5.8 \%$ \\
\hline Mitsubishi Heavy & $95-05$ & Topix & 0.94 & $-8.9 \%$ & $-2.9 \%$ & $7.1 \%$ \\
\hline Northrop Grumman & $95-05$ & S\&P 500 & 0.47 & $9.4 \%$ & $9.0 \%$ & $5.9 \%$ \\
\hline Oshkosh Truck & $95-05$ & S\&P 500 & 0.55 & $32.9 \%$ & $9.0 \%$ & $8.4 \%$ \\
\hline Raytheon & $95-05$ & S\&P 500 & 0.55 & $1.7 \%$ & $9.0 \%$ & $7.9 \%$ \\
\hline Rheinmettall DeTec & $95-05$ & $\operatorname{Dax} 30$ & 0.20 & $10.6 \%$ & $6.8 \%$ & $8.1 \%$ \\
\hline Rockwell Collins & $01-05$ & S\&P 500 & 0.95 & $17.6 \%$ & $-1.1 \%$ & $4.4 \%$ \\
\hline Rolls-Royce & $95-05$ & FTSE All & 1.09 & $3.1 \%$ & $4.3 \%$ & $7.7 \%$ \\
\hline Saab & $98-05$ & Affarsvarlben & 0.34 & $4.3 \%$ & $1.2 \%$ & $5.3 \%$ \\
\hline Silicon Graphics & $95-05$ & S\&P 500 & 1.33 & $-22.5 \%$ & $9.0 \%$ & $17.5 \%$ \\
\hline Singapore Tech. Eng. & $97-05$ & Singapore ST & 0.71 & $8.2 \%$ & $3.4 \%$ & $6.2 \%$ \\
\hline Smiths Industries & $95-05$ & FTSE All & 0.72 & $6.4 \%$ & $4.3 \%$ & $5.9 \%$ \\
\hline Snecma (Sagem) & $95-05$ & SBF 120 & 0.48 & $6.9 \%$ & $7.5 \%$ & $8.2 \%$ \\
\hline Stewart \& Stevenson & $95-05$ & S\&P 500 & 0.73 & $-3.2 \%$ & $9.0 \%$ & $9.4 \%$ \\
\hline
\end{tabular}




\begin{tabular}{|c|c|c|c|c|c|c|}
\hline Company & $\begin{array}{l}\text { Time } \\
\text { Period }\end{array}$ & $\begin{array}{l}\text { Market } \\
\text { Index }\end{array}$ & $\hat{\square}$ & $\begin{array}{c}\text { Annualized } \\
\text { price } \\
\text { return }\end{array}$ & $\begin{array}{c}\text { Market } \\
\text { annualized } \\
\text { price } \\
\text { return }\end{array}$ & $\begin{array}{c}\operatorname{GARCH}(1,1) \\
\text { volatility }\end{array}$ \\
\hline Tadiran Com. & $00-05$ & Israel TA 100 & 0.88 & $41.9 \%$ & $4.2 \%$ & $7.7 \%$ \\
\hline Teledyne Technologies & $99-05$ & S\&P 500 & 1.12 & $25.0 \%$ & $-3.3 \%$ & $9.1 \%$ \\
\hline Textron & $95-05$ & S\&P 500 & 0.87 & $10.7 \%$ & $9.0 \%$ & $6.2 \%$ \\
\hline Thales & $95-05$ & SBF 120 & 0.81 & $2.4 \%$ & $7.5 \%$ & $8.0 \%$ \\
\hline ThyssenKrupp Werften & $95-05$ & Dax 30 & 0.79 & $-0.4 \%$ & $6.8 \%$ & $6.8 \%$ \\
\hline Titan & $95-05$ & S\&P 500 & 0.94 & $12.6 \%$ & $9.0 \%$ & $12.6 \%$ \\
\hline Ultra Electronics & $96-05$ & FTSE All & 0.16 & $13.0 \%$ & $2.2 \%$ & $3.5 \%$ \\
\hline United Defense Indus. & $01-05$ & S\&P 500 & 0.32 & $45.5 \%$ & $0.7 \%$ & $4.0 \%$ \\
\hline United Technologies & $95-05$ & S\&P 500 & 0.97 & $18.9 \%$ & $9.0 \%$ & $6.3 \%$ \\
\hline URS & $95-05$ & S\&P 500 & 0.60 & $17.8 \%$ & $9.0 \%$ & $8.9 \%$ \\
\hline VT Group & $95-05$ & FTSE All & 0.16 & $7.2 \%$ & $4.3 \%$ & $3.9 \%$ \\
\hline Washington Group Int. & $02-05$ & S\&P 500 & 0.42 & $6.3 \%$ & $0.7 \%$ & $3.8 \%$ \\
\hline
\end{tabular}

Note: In this table, market model parameters are estimated with conditional heteroskedasticity GARCH $(1,1)$ by the maximum likelihood method on the whole time period. The sample contains 58 publicly listed firms included in the "World Top 100 Defense firms". The time period extends from January 1995 to May 2005. 


\section{Appendix 3 - News categories}

We detail in this appendix the news categories used to classify all the information releases which are likely to influence stock prices of defense firms. An example of a news release classified in each category is provided.

\begin{tabular}{|c|c|c|}
\hline \multicolumn{2}{|c|}{ 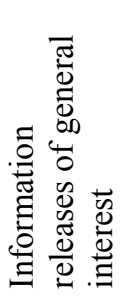 } & $\begin{array}{l}\text { Geopolitical event and macroeconomic news (POLITICS): News items related to geopolitical, political or } \\
\text { macroeconomic events. Even as the major U.S. equity averages plunged Monday in the wake of the Sept. } 11 \\
\text { terrorist attacks, investors bid up shares of companies expected to benefit from a more-security-conscious, less- } \\
\text { peaceful world. } \\
\text { Changes in public spending related to defense (PUBSPEND): Announcements or rumors related to changes in } \\
\text { public spending in defense. Elbit Systems, a maker of defense electronics, fell } 4.5 \% \text { to NIS } 65.80 \text {. Defense News } \\
\text { said Israeli military exports will drop } 40 \% \text { to } \$ 2.5 \text { billion this year, citing an official in the defense ministry }\end{array}$ \\
\hline \multirow{3}{*}{ 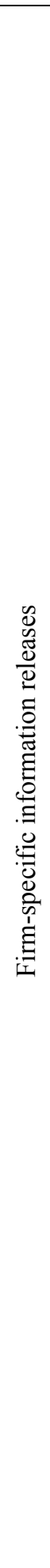 } & 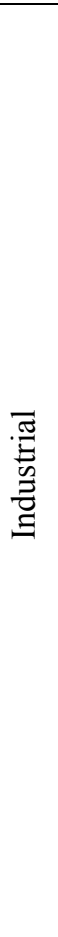 & $\begin{array}{l}\text { Company restructuring (RESTRUCT): Announcements or rumors related to firms' reorganizations and disposal } \\
\text { of subsidiaries. This category does not include the announcements related to capital restructuring. The Harris } \\
\text { Corporation, which is moving to concentrate on communications equipment, said late yesterday that it would spin } \\
\text { off Lanier Worldwide. } \\
\text { Labor related issues (LABOR): News items relating to lay-offs, employees' pay settlements, new incentive } \\
\text { schemes, etc. Textron Inc. will lay off } 1,200 \text { employees in its Cessna Aircraft unit, citing a reduction in the order } \\
\text { placed by one of its two major business jet customers and worldwide economic concerns. } \\
\text { Contracts (CONTRACT): News items relating to negotiation, conclusion or breach of contract. Harris Corp. } \\
\text { received } \$ 222 \text { million contract from U.S. Army Communications-Electronics Command (CECOM) for } 205 \\
\text { Lightweight Multiband Satellite Terminals (LMSTs), company said. } \\
\text { Product information (PRODUCT): News items relating to capabilities, expectations about success, market } \\
\text { potentials of existing or news products. The U.S. Army reports that its next-generation RF electronic combat suite } \\
\text { developed by ITT-Industries took its first flight on March 23, 1999. ITT Industries, Avionics Division is the prime } \\
\text { contractor for the AN/ALQ-211 SIRFC system. } \\
\text { Review of company prospects - other than analysts (PROSPECT): Issues relating to the review of a company's } \\
\text { prospects not published by a sell-side analyst. The Oshkosh Truck Corporation said yesterday that its commercial } \\
\text { sales will be lower than expected amid a softening in North America's concrete-placement market. } \\
\text { Strategic alliance between two firms for developing a new product (STRAT): News items relating to the } \\
\text { announcement or the rumor about a strategic or industrial alliance between firms (this category excludes the case } \\
\text { for financial alliances, included in the bid category). Finmeccanica SpA unit Alenia Difesa said it and Deutsche } \\
\text { Aerobus AG unit Dornier signed a memorandum of understanding to jointly develop an anti-submarine MPA } \\
\text { aircraft to replace the Breguet Atlantic } 1150 \text {. }\end{array}$ \\
\hline & 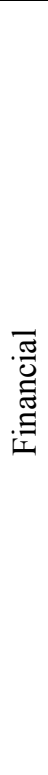 & $\begin{array}{l}\text { Bids and speculation about bids (BIDS): Announcements or published rumors in relation to take-overs, } \\
\text { acquisitions and mergers. DRS Technologies, Inc. today confirmed that it has held discussions with a financial } \\
\text { buyout group concerning the possible acquisition of DRS. These discussions have been terminated. } \\
\text { Financing issues (FINANCE): News items relating to issuance of shares or bonds, capital restructuring, share } \\
\text { repurchase, etc. The company was in crisis talks with its bank syndicate after it breached its agreed debt level of } 3.5 \\
\text { times its cash-flow for a loan worth } 358 \text { mln eur. } \\
\text { Analysts (ANALYST): Sell-side analysts' recommendations and forecasts. Cobham advanced } 67-1 / 2 \text { pence to } 787- \\
1 / 2 \text { buoyed by news CSFB had reiterated its 'buy' rating with a } 900 \text { pence price target. } \\
\text { Earnings related news (EARNINGS): News items relating to a (formal or not) announcement by the firm } \\
\text { regarding its current or expected earnings, excluding the special case of a formal profit warning. CACI said its } \\
\text { profits rose } 54 \text { percent from the same period in the previous fiscal year. } \\
\text { Profit warning (WARNING): Firm announcements regarding expected profits. Textron Inc. officials announced } \\
\text { Sept. } 26 \text { that the company is lowering its earnings estimates for the third and fourth quarters of this year. } \\
\text { Share deals (SHAREDEAL): News items relating to large trading activity in a firm's shares (institutional } \\
\text { purchases or sales). According to information obtained by Handelsblatt, U.S. investor Guy Wyser-Pratte has } \\
\text { acquired } 5.054 \% \text { of Rheinmetall's ordinary shares and } 1.1 \% \text { of its pre-ference shares. A spokesman for Rheinmetall } \\
\text { confirmed that Wyser-Pratte had acquired a stake in the group. However, he said it was too early to comment on } \\
\text { the matter. }\end{array}$ \\
\hline & & $\begin{array}{l}\text { Management issues (MANAG): News items relating to appointments, dismissals, retirements or compensation } \\
\text { schemes of top managers. Northrop Grumman Corp. stumbled along with other defense firms Thursday, a day after } \\
\text { the company announced a change at the top of its executive ladder. } \\
\text { Legal issues (LEGAL): Legal issues, trials, penalties. ManTech International Corp. said yesterday that the Defense } \\
\text { Department last month subpoenaed company information related to a contract for security and personnel } \\
\text { background checks. }\end{array}$ \\
\hline
\end{tabular}

No relevant information releases 


\section{Appendix 4 - Daily abnormal returns following September 112001}

\begin{tabular}{|c|c|c|c|c|c|c|c|}
\hline Alliant Techsystems & US & $20 \%$ & 09/17/2001 & Kongsberg Gruppen & Norway & ns. & \\
\hline Alvis & UK & ns. & & L-3 communications & US & $35 \%$ & $09 / 17 / 2001$ \\
\hline Babcock Intern. Group & UK & $-8 \%$ & $09 / 20 / 2001$ & Lockheed Martin & US & $16 \%$ & $09 / 17 / 2001$ \\
\hline BAE Systems & UK & $9 \%$ & $09 / 11 / 2001$ & Meggitt & UK & $-4 \%$ & $09 / 12 / 2001$ \\
\hline Bearing Point & US & $-7 \%$ & 09/19/2001 & Mitsubishi Heavy & Japan & $7 \%$ & $09 / 13 / 2001$ \\
\hline Bharat Electronics & India & $-4 \%$ & $09 / 14 / 2001$ & Northrop Grumman & US & $17 \%$ & $09 / 17 / 2001$ \\
\hline Boeing & US & $-15 \%$ & $09 / 17 / 2001$ & Oshkosh Truck & US & $8 \%$ & $09 / 17 / 2001$ \\
\hline CACI & US & $23 \%$ & $09 / 17 / 2001$ & Raytheon & US & $26 \%$ & $09 / 17 / 2001$ \\
\hline CAE & Canada & $-5 \%$ & $09 / 11 / 2001$ & Rheinmettall DeTec & Germany & $4 \%$ & $09 / 11 / 2001$ \\
\hline Cobham & UK & $-4 \%$ & $09 / 17 / 2001$ & Rockwell Collins & US & $-16 \%$ & $09 / 17 / 2001$ \\
\hline Cubic & US & $10 \%$ & $09 / 17 / 2001$ & Rolls-Royce & UK & $-6 \%$ & $09 / 14 / 2001$ \\
\hline Dassault Aviation & France & $-8 \%$ & $09 / 13 / 2001$ & Saab & Sweden & $5 \%$ & $09 / 18 / 2001$ \\
\hline DRS Technologies & US & $24 \%$ & $09 / 12 / 2001$ & Silicon Graphics & US & $-15 \%$ & $09 / 20 / 2001$ \\
\hline EADS & France & $-9 \%$ & $09 / 12 / 2001$ & Singapore Tech. Eng. & Singapore & $7 \%$ & $09 / 12 / 2001$ \\
\hline EDO & US & $24 \%$ & $09 / 17 / 2001$ & Smiths Industries & UK & $-3 \%$ & $09 / 11 / 2001$ \\
\hline Elbit Systems & Israel & $3 \%$ & $09 / 12 / 2001$ & Snecma (Sagem) & France & $-13 \%$ & $09 / 14 / 2001$ \\
\hline Finmeccanica & Italy & $-5 \%$ & $09 / 11 / 2001$ & Stewart \& Stevenson & US & $9 \%$ & $09 / 17 / 2001$ \\
\hline General Dynamics & US & $12 \%$ & $09 / 17 / 2001$ & Tadiran Com. & Israel & $-8 \%$ & $09 / 11 / 2001$ \\
\hline GKN Group & UK & $-4 \%$ & $09 / 13 / 2001$ & Teledyne Technologies & US & $22 \%$ & $09 / 17 / 2001$ \\
\hline Goodrich & US & $-16 \%$ & $09 / 17 / 2001$ & Textron & US & $-6 \%$ & $09 / 17 / 2001$ \\
\hline Halliburton & US & $-8 \%$ & $09 / 18 / 2001$ & Thales & France & $6 \%$ & $09 / 12 / 2001$ \\
\hline Harris & US & $14 \%$ & $09 / 17 / 2001$ & ThyssenKrupp Werften & Germany & $-4 \%$ & $09 / 13 / 2001$ \\
\hline Honeywell & US & $-13 \%$ & $09 / 17 / 2001$ & Titan & US & $18 \%$ & $09 / 17 / 2001$ \\
\hline Indra Sistemas & Spain & $8 \%$ & $09 / 12 / 2001$ & Ultra Electronics & UK & $-3 \%$ & $09 / 12 / 2001$ \\
\hline ITT Industries & US & $3 \%$ & $09 / 18 / 2001$ & United Technologies & US & $-28 \%$ & $09 / 17 / 2001$ \\
\hline Jacobs Eng. Group & US & $9 \%$ & $09 / 17 / 2001$ & URS & US & $16 \%$ & $09 / 17 / 2001$ \\
\hline Kawasaki Heavy Indus. & Japan & $-20 \%$ & $09 / 19 / 2001$ & VT Group & UK & $-3 \%$ & $09 / 12 / 2001$ \\
\hline
\end{tabular}

Note: Abnormal returns are computed given the market model parameters which are estimated with conditional heteroskedasticity GARCH(1,1) by the maximum likelihood method through the estimation window $[-120 ;-1]$ in event time. n.s.: non significant at the $5 \%$ level. 